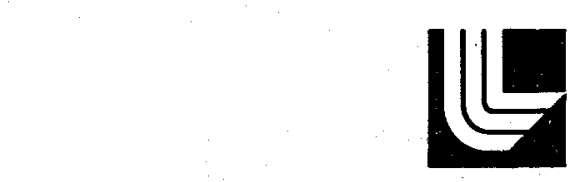

LAWRENCEE LIVERMORE LABORATORY

University of Callfornia/Livermore, California 94550

UCRL-52252

\title{
POTENTIAL GROWTH OF ELECTRIC POWER PRODUCTION FROM IMPERIAL VALLEY GEOTHERMAL RESOURCES
}

D. L. Ermak

September 30, 1977

\begin{tabular}{|c|}
\hline 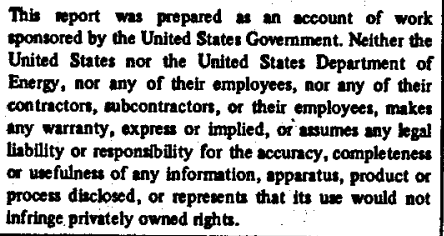 \\
\hline
\end{tabular}

Thb wport was propared as an sccount of work

ponsored by the United States Govemment. Neither the

Energer States nor the Uaitod States Department of

contractorn, wobcontractors, of their employees, makes

infringe privately ownod rights. 


\section{DISCLAIMER}

This report was prepared as an account of work sponsored by an agency of the United States Government. Neither the United States Government nor any agency Thereof, nor any of their employees, makes any warranty, express or implied, or assumes any legal liability or responsibility for the accuracy, completeness, or usefulness of any information, apparatus, product, or process disclosed, or represents that its use would not infringe privately owned rights. Reference herein to any specific commercial product, process, or service by trade name, trademark, manufacturer, or otherwise does not necessarily constitute or imply its endorsement, recommendation, or favoring by the United States Government or any agency thereof. The views and opinions of authors expressed herein do not necessarily state or reflect those of the United States Government or any agency thereof. 


\section{DISCLAIMER}

Portions of this document may be illegible in electronic image products. Images are produced from the best available original document. 


\section{Contents}

Abstract ............................. 1

Introduction . . . . . . . . . . . . . . . . . . . . . 1

Geothermal Growth Scenario . . . . . . . . . . . . . . . . 3

Current Situation . . . . . . . . . . . . . . . . 3

Geothermal Power Projections . . . . . . . . . . . . . 4

Power Plant Siting Scenario . . . . . . . . . . . . . . . . 7

Siting Criteria ......................... 7

Resource and Technology Constraints . . . . . . . . . 7

Institutional Constraints .............. 9

Other Land Use Constraints . . . . . . . . . . . . 11

Power Plant Sites . . . . . . . . . . . . . . . . . 12

Energy Technology Characterization Scenario . . . . . . . . . . . 16

Geothermal Electric Power Development Analysis . . . . . . . . . . . 20

Power Plant Construction and Well Drilling Rates . . . . . . . 20

Land Use . . . . . . . . . . . . . . . . . . . 22

Cooling Water Requirements . . . . . . . . . . . . . 23

Hydrogen Sulfide Emissions . . . . . . . . . . . . . . 25

Acknowledgments . . . . . . . . . . . . . . . . . . 27

References ............................ . . . . 28 


\title{
POTENTIAL GROWTH OF ELECTRIC POWER PRODUCTION FROM IMPERIAL VALLEY GEOTHERMAL RESOURCES
}

\begin{abstract}
The growth of geothermal electric power operations in Imperial Valley, California is projected over the next 40 years. With commercial power forecast to become available in the 1980's, the scenario considers three subsequent growth rates: 40,100 , and 250 MW per year. These growth rates, along with estimates of the total resource size, result in a maximum level of electric power production ranging from 1000 to $8000 \mathrm{MW}$ to be attained in the 2010 to 2020 time period. Power plant siting constraints are developed and used to make siting

patterns for the 400- through 8000-MW level of power production. Two geothermal technologies are included in the scenario: flashed steam systems that produce cooling water from the geothermal steam condensate and emit noncondensable gases to the atmosphere; and high pressure, confined flow systems that inject the geothermal fluid back into the ground. An analysis of the scenario is made with regard to well drilling and power plant construction rates, land use, cooling water requirements, and hydrogen sulfide emissions.
\end{abstract}

\section{Introduction}

This report presents a scenario of the potential growth of geothermallyproduced electric power in Imperial Valley, California, over the next 40 years. Utilization of these resources is in the exploratory and developmental stages with no geothermal power plants in operation. However, developers are currently exploring methods of exploiting these resources and are planning to have several small power plants (10-50 MW) on-line within the next 3 years.

The purpose of this report is to provide a quantitative description of the potential levels of geothermal electric power development. The scenario is presented in three parts: electric power growth projections, power plant siting patterns, and energy technology characterization. The growth projections are based on historical growth rates and current estimates of the resource size. 
Power plant siting criteria are developed taking into consideration the nontransportable nature of geothermal energy, institutional constraints, and other land use restrictions. These criteria are used to make power plant siting patterns for the power levels given in the growth projections. Individual power plants are described in terms of their rates of resource consumption and waste disposal. In the conclusion of the report, a brief analysis of the scenario is given with regard to well drilling and power plant construction rates, land use, cooling water requirements, and hydrogen sulfide $\left(\mathrm{H}_{2} \mathrm{~S}\right)$ emissions to the atmosphere.

Emphasis is placed on large scale development as opposed to a single, site-specific power plant. This approach provides a basis where assessments can be made of the long term environmental and socioeconomic impacts. The Integrated Assessment group of the Imperial Valley Environmental Project (IVEP) is currently using this scenario for such an assessment, which will hopefully help to identify the adverse impacts that must be overcome in order for geothermal development to proceed in an environmentally and economically sound manner.

The information used to develop this scenario was obtained from open literature, private industry, county and state government agencies, and Lawrence Livermore Laboratory staff. As new information concerning the growth of geothermal operations in Imperial Valley is made available, it will be incorporated into the scenario and used in future IVEP impact assessments. 


\section{Geothermal Growth Scenario}

CURRENT SITUATION

Imperial Valley contains four Known Geothermal Resource Areas (KGRA's) that are considered potentially suitable for electric power generation (see Fig. 1). While only a small percentage of the total resource has been explored by well drilling, total resource size estimates have been made using less direct methods. ${ }^{1-3}$ Recent estimates place the potential electric power production of the resource to be between 3000 and 5000 MW for a 30-year period $(90,000$ to $150,000 \mathrm{MW}-\mathrm{yr}) .^{1,4}$ Approximately $60 \%$ of the total resource is estimated to be in the Sa1ton Sea KGRA.

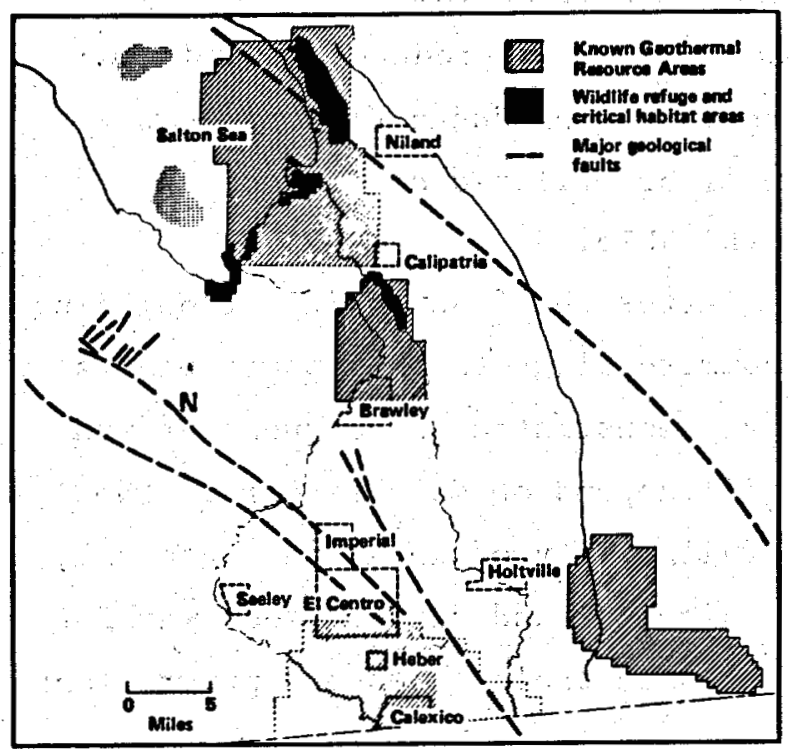

Fig. 1. Imperial Valley KGRA's considered to be suited for electric power production. Also shown are wildlife refuge and critical habitat areas and major geological faults.
The average downhole temperature of the geothermal fluids is approximately $285^{\circ} \mathrm{C}$ in the Salton Sea KGRA and ranges from 180 to $200^{\circ} \mathrm{C}$ in the other KGRA's. While fluids in the Salton Sea KGRA are of a higher quality from a temperature standpoint, they also have an extremely high total dissolved solids (TDS) content, being $200,000 \mathrm{ppm}$ on the average. (For comparison, the TDS of sea water is approximately 33,000 ppm.) The high TDS content of these brines presents the major technological problem to large scale development. These brines are highly corrosive and cause rapid scale formation. 6 For commercial production of electric power from these resources, extensions of existing technology are needed. In the southern part of the Valley, the TDS of the geothermal fluids is lower: approximately $20,000 \mathrm{ppm}$ in Heber and 2000 ppm in East Mesa.

Many research and development projects are being conducted in each Imperial Valley KGRA with the goals of extending geothermal exploration and overcoming technological difficulties. For example, San Diego Gas and Electric Co. (SDG\&E) is operating a 10-MW test facility in the Salton Sea KGRA. Lawrence Livermore Laboratory is developing a total flow conversion technology, specifically 
designed for the highly saline brines of the Salton Sea areas. Union Oil Co. is actively drilling exploratory geothermal wells in the Brawley KGRA. In the Heber KGRA, SDG\&E is planning to build a 45-MW commercial power plant by 1980. Magma Power Co. is planning to build a 10-MW demonstration facility in the East Mesa KGRA by 1978. Republic Geothermal Co. has applied for a U.S. Energy Research and Development Administration (ERDA) loan guarantee to build a 48-MW developmental power plant in the East Mesa KGRA and is actively drilling geothermal wells in the Westmorland area south of the Salton Sea.

Several forecasts of the geothermal electric power production growth rate have been made assuming that the economic feasibility of such operations is demonstrated within the next decade. $^{7-10}$ For 1995 , estimates of available commercial electric power from Valley geothermal resources range from a low of $500 \mathrm{MW}$ to a high of 13,000 MW. The wide range in these forecasts reflects the variation in the estimates of resource size and the uncertainty in overcoming technological problems associated with high TDS brines in the Salton Sea area .

GEOTHERMAL POWER PROJECTIONS

Table 1 summarizes the growth scenario proposed in this work for developing commercially available electric power from Valley geothermal resources. Inherent in this scenario are several assumptions that are independent of the specified growth rate. First, it is assumed that technologies are developed within the next 10 years for producing electricity from highly saline brines at a price competitive with other power technologies. Second, as geothermal exploration continues by well drilling, the resource is sufficiently large to support large scale development (greater than several hundred MW). Finally, future demand for additional electric power in the southern California region will greatly exceed the ability of Valley geothermal developers to produce it; and geothermally produced electric power will be utilized as it becomes available.

After the feasibility of building commercial geothermal power plants is demonstrated, subsequent growth will depend on many factors: the availability of investment capital, equipment, and skilled manpower for resource exploration and power plant construction; the rate at which county and state permits for geothermal development are approved; and the public attitude toward geothermal growth in their 1ocale. No attempt 
Table 1. Geothermal growth scenario.

\begin{tabular}{|c|c|c|c|c|c|c|c|}
\hline \multicolumn{3}{|c|}{ Year power level attained } & \multirow[b]{2}{*}{$\begin{array}{c}\text { Power level, } \\
\text { MW }\end{array}$} & \multicolumn{4}{|c|}{ Power distribution, $\mathrm{MW}$} \\
\hline $\begin{array}{c}\text { High } \\
\text { growth } \\
\text { projection }\end{array}$ & $\begin{array}{l}\text { Medium } \\
\text { growth } \\
\text { projection }\end{array}$ & $\begin{array}{c}\text { Low } \\
\text { growth } \\
\text { projection }\end{array}$ & & $\begin{array}{c}\text { Salton } \\
\text { Sea }\end{array}$ & Brawley & Heber & $\begin{array}{l}\text { East } \\
\text { Mesa }\end{array}$ \\
\hline 1980 & 1982 & 1986 & 100 & -- & -- & -- & -- \\
\hline 1982 & 1985 & 1994 & 400 & 100 & 100 & 100 & 100 \\
\hline 1984 & 1991 & 2010 & 1000 & 300 & 300 & 300 & 100 \\
\hline 1991 & 2010 & Never & 3000 & 1400 & 600 & 700 & 300 \\
\hline 2010 & Never & Never & 8000 & 4000 & 1400 & 1800 & 800 \\
\hline
\end{tabular}

has been made to treat these factors separately and quantitatively. Rather, they are treated in the aggregate by specifying low, medium, and high growth projections (see Fig. 2). The growth range provided in these projections is intended to encompass the most highly probable development levels.

The medium growth projection has a growth rate that is based on the historical growth rate at The Geysers and assumes the geothermal resource size is within current estimate limits. Growth at The Geysers is currently about $100 \mathrm{MW}$ per year and is expected to continue at this rate for a number of years. ${ }^{11}$ In the

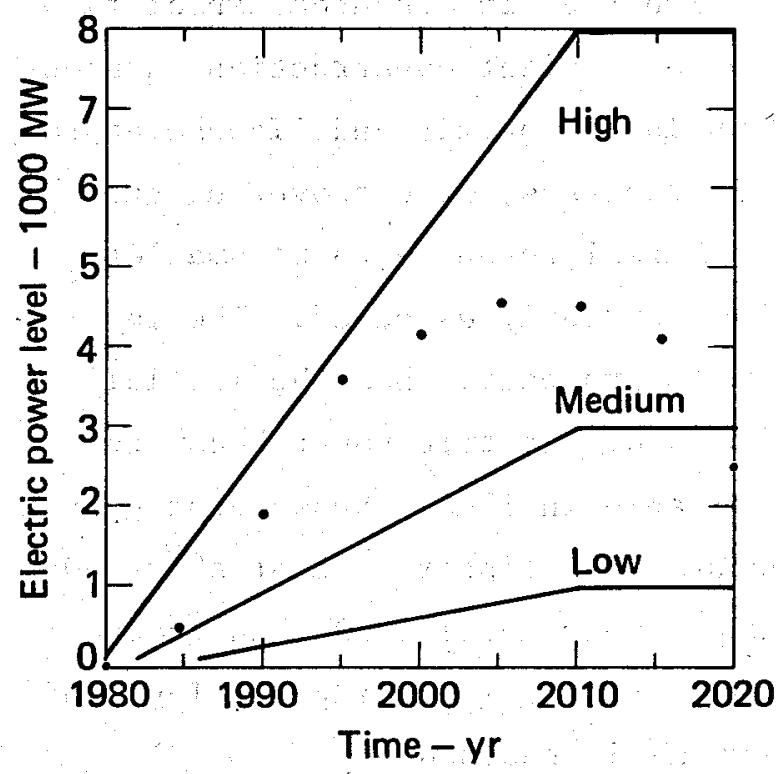

Fig. 2. Projected growth rates of geothermal electric power production in Imperial Valley. Also shown (dots) is the national geothermal goal proposed by ERDA for the Valley resource.

medium growth projection, the first $100 \mathrm{MW}$ of electric power* is produced in 1982 with subsequent growth at a linear rate of 100 MW per year for the next 28 years. The maximum production level is $3000 \mathrm{MW}$ attained in 2010 .

*Power levels presented in this report represent yearly average levels of electric power produced. A 110-MW capacity power plant with an operation factor of $90 \%$ will have a power level of $100 \mathrm{MW}$. 
Assuming a power plant life of 30 years and no new power plants are to be built after 2020, the medium growth projection requires a total electrical energy production of $120,000 \mathrm{MW}-\mathrm{yr}$.

This energy requirement is equivalent to $4000 \mathrm{MW}$ for 30 years and is therefore consistent with current resource estimates.

Growth is significantly restricted in the low growth projection. Reduced growth could be due to technological difficulties in resource exploration and power plant construction, a slowdown in the permit and license approval processes, or discovering the geothermal resource to be smaller than currently expected. The low growth projection has the initial $100 \mathrm{MW}$ of electric power becoming available in 1986. Subsequent growth occurs at a linear rate of about 40 MW per year until 2010 when growth stops and the maximum power level of $1000 \mathrm{MW}$ is reached. .

The high growth projection assumes that growth is accelerated and the geothermal resource is about three to four times as large as current estimates indicate. The first $100 \mathrm{MW}$ of electric power is projected to be available in 1980. Subsequent growth occurs at a rate of about $250 \mathrm{MW}$ per year until 2010 when growth stops and a maximum power level of $8000 \mathrm{MW}$ is produced.

At the lower levels of geothermal development, the scenario distributes the production of electric power evenly among the four Imperial Valley KGRA's. This situation reflects the current interest and activity in each KGRA. As development continues, the percentage of power produced in the Salton Sea KGRA grows while that in the East Mesa KGRA decreases so as to approach the predicted levels of geothermal resource available in each KGRA. At the highest levels of production, half the commercially available power is being produced in the Salton Sea KGRA. 


\section{Power Plant Siting Scenario}

Development of the power plant siting scenario is accomplished in two steps. A set of criteria is first developed for designating certain geographical areas as suitable for geothermal development. Power plants are then sited in designated regions of the four Imperial Valley KGRA's with initial sites in the vicinity of current geothermal operations. Using this approach, siting patterns were obtained for the range of power levels presented in the growth scenario.

It should be emphasized that the siting locations are not intended. to be predictions of the actual locations of future power plants. Rather, they are hypothetical locations chosen from regions that appear suitable for geothermal development. The siting scenario provides a quantitative description of the number and general siting pattern of power plants that could be expected at the profected.1evels of geothermal

development.

\section{SITING CRITERIA}

Numerous factors determine the suitability of a reglon for developing geothermal power plants: resource location, water availability, proxmity to urban areas, conflicts in land use, seismic risk, etc. A discussion of the factors taken into consideration is presetned under the headings of Resource and Technology Constraints, Institutional Constraints, and Other Land Use Constraints. The specific criteria adopted for this work are delineated at the end of each section.

Resource and Technology Constraints

Geothermal energy is unique in comparison to other energy resources (such as fossil fuel or nuclear) because it must be utilized where it is discovered. Heat losses in pipe lines restrict the transportation of geothermal fluids to 1 or 2 miles. 12 As a result, geothermal fluids cannot be transported long distances to a power plant at a more favorable location, but must be converted to electricity in the vicinity of the well field.

The nontransportable nature of the fluids and the finite energy density of the resource also limit the maximum size (electrical capacity) of a geothermal power plant. Supporting wells are normally spaced so that one does not affect the other. Additional space must be left for makeup wells as well life is generally shorter 
than the designed power plant life. Consequently, the capacity of a power plant is limited since fluids cannot be obtained from wells beyond 1 or 2 miles. Commercial power plants have typically been 50 to 150 MW in size. For example, the Cerro Prieto plant has a 75-MW capacity while the generating units at The Geysers range from 11 to $110 \mathrm{MW}$ with the smaller units being built first.

The size (land surface area) of the well field required to support a $100-\mathrm{MW}$ power plant for 30 years varies with the characteristics of the geothermal resource. Using arguments based on typical well yields and well spacings, Hughes ${ }^{13}$ gives a general estimate of approximately $1 \mathrm{mi}^{2}$ to support a $100-\mathrm{MW}$ power plant. A major controlling factor of the well field size is the temperature of the geothermal fluids: Electrical yield increases with the geothermal resource temperature so that less fluid (and therefore fewer wells and less land area) is needed as the resource temperature rises. Using the GEOTHM computer program, Pines and Green ${ }^{14}$ have designed power plants that utilize geothermal fluids with a high TDS content and at temperatures nearly equal to those found in Imperial Valley. Their calculations indicate that half as much geothermal fluid at $300^{\circ} \mathrm{C}$ is required to produce a given electrical output than is required if the fluid temperature is only $200^{\circ} \mathrm{C}$. This result suggests that well field sizes in the Salton Sea KGRA will be approximately half as large as those in the other KGRA's for the identical capacity power plant.

The preceding considerations lead to the following assumptions and constraints that are adopted for the siting scenario:

- Those Imperial Valley geotherma1 resources that are suitable for commerical power development exist within the current boundaries of the Salton Sea, Brawley, Heber, and East Mesa KGRA's as specified by the U.S. Geological Survey. An exception to this rule is the high growth projection of 8000 MW, in which the resource is assumed to be larger than currently estimated. In this case the resource is assumed to extend into the Westmorland area between the Salton Sea and Brawley KGRA's.

- Power plants and well fields are located within the boundaries of the resource, as given in the preceding assumption. 
- Power plants are sited in 100MW units with a 30-year life span (110-MW capacity with a $90 \%$ operation factor).

- The well field size required to support a 100-MW power plant is:

Salton Sea $-1.25 \mathrm{mi}^{2}$

$\left.\begin{array}{l}\begin{array}{l}\text { Brawley } \\ \text { Heber } \\ \text { East Mesa }\end{array}\end{array}\right\}-2.50 \mathrm{mi}^{2}$

\section{Institutional Constraints}

A number of federal and local governmental agencies have regulatory authority in power plant siting. 15 At the Federal level, the Secretary of the Interior has the responsibility for designating endangered and threatened species, critical habitats, and wildlife refuges; and for leasing geothermal resources on federal lands. License granting authority is generally administered by state agencies, as is the leasing of state lands. Local governments exercise control over power plant siting by regulating permits, instituting zoning ordinances, and by their authority to protect health and welfare.

The Secretary of the Interior and the California Department of Fish and Game have listed five endangered species that are known to occur in Imperial Valley. ${ }^{16}$ of these, four are migratory and one, the Yuma clapper rail, is a nesting inhabitant. Figure 1 shows the areas covered by the Salton Sea National Wildlife Refuge, the Wister and Finney-Ramer units of the Imperial Management Area, and the Yuma clapper rail critical habitat. These regions occupy sma11 areas in both the Salton Sea and Brawley KGRA's.

The California Energy Resources Conservation and Development Commission (ERCDC) is the state licensing agency for power plants over $50 \mathrm{MW}$. The energy commission has exclusive jurisdiction to certify all power plant sites and related facilities. ERCDC's siting division has issued a draft copy of the required considerations for power plant operator Notice of Intents. This list includes several institutional and 1 and userelated sections, primarily based on county ordinances and local land use plans, and therefore leave siting control at the local level.

At the local level, Imperial County has three documents on record $^{17-19}$ that place limitations on the siting of geothermal operations. The county is in the process of developing a "Geothermal Element" to the Imperial County General Plan; however, it is not completed.

The zones in which geothermal operations would be permitted according to the Imperial County Current 
Table 2. Imperial County zoning constraints.

\begin{tabular}{|c|c|}
\hline $\begin{array}{c}\text { Geothermal activity } \\
\text { permitted }\end{array}$ & $\begin{array}{c}\text { Geothermal activity } \\
\text { not permitted }\end{array}$ \\
\hline
\end{tabular}

Imperial Valley Current Land Use Plan

Agricultural zones A-2, A-2-R, A-3

All residential zones

Manufacturing zone $\mathrm{M}-2$

Agricultural zones R-A, A-1

All commercial zones

Manufacturing zone $\mathrm{M}-1$

Recreation zone $\mathrm{F}$

Open space zone $\mathrm{S}$

Imperial Valley UItimate Land Use Plan

General agriculture

Heavy industry

Recreation
Urban

Preservation

Rural and desert residential Special public
Zoning Plan and the Ultimate Land Use Plan are listed in Table 2 and are mainly the agriculture, industry, and recreation zones. The Terms, Conditions, Standards, and Application Procedures for Initial Geothermal Development document lists minimum separation distances (buffer zones) between a geothermal well and various facilities: e.g., hospital $1 \mathrm{mi}$, school 1/4 mi. Similar buffer zones for commercial geothermal power plants have not been established but are expected to be similar to those for geothermal wells.

In summary, the institutional criteria included in the siting scenario are:
- Power plant operations are not located in the wildlife refuge and critical habitat areas shown in Fig. 1.

- Power plant operations are sited in accordance with the Imperial Valley Current Zoning Plan and Ultimate Land Use Plan.

- Power plant operations are excluded from the following buffer zones:

\begin{tabular}{lc} 
Facility & $\begin{array}{c}\text { Buffer distance } \\
(\mathrm{mi})\end{array}$ \\
\cline { 2 - 2 } $\begin{array}{l}\text { Hospital } \\
\text { School }\end{array}$ & 1.0 \\
$\begin{array}{l}\text { Municipal } \\
\text { boundary }\end{array}$ & 0.5 \\
& 0.5
\end{tabular}


Other Land Use Constraints

The following additional criteria are included in the siting scenario:

- Most of the area where geothermal power plants can be located is over agricultural land. Since Imperial Valley is one of the most valuable agricultural resources in the nation; it is expected that geothermal development will not be allowed to significantly impair this industry, and efforts will be made to minimize the land area occupied by geothermal facilities (wells, pipellnes, generator building, storage areas, etc.). In this scenario, land area for geothermal facilIties is 1imited to 20 acres per 100-MW unit. In addition, agreements between the utilities and private land owners concerning leasing or buying land for power plant operations are assumed to be readily attained.

In order to maintain compatibility with agriculture, measures can be taken to reduce land consumption and minimize interference with agricultural activity. For example, power plants can be located at the edge of agricultural parcels and adjacent to existing roads.
Several geothermal wells can be drilled from the same location using slant drilling. Also, pipelines from the wells to the conversion facility can be laid parallel to existing roads.

In comparison to the 20-acre per unit limit, the SDG\&E/ERDA 10-MW test facility in the Salton Sea KGRA occupies 18.2 acres. Two acres are included for a spray pond and approximately one acre for the process area. Commercial power plants are expected to use wet cooling towers that occupy considerably less land area than the equivalent spray pond. Geothermal wells at the test facility are encompassed in a. $20-\mathrm{ft}^{2}$ area.

- Power plants will not be sited over the Salton Sea due to the increased construction costs.

- Power plants w111 not be located within $1 / 4 \mathrm{mi}$ of efther side of a major fault so as to reduce the risk of damage due to seismic activity. A major fault is considered to be either a fault with reported surface rupture during the past 200 years, a fault with inferred recent movement, or a fault that appears to displace Quaternary rocks. (The major faults in 
Imperial Valley are shown in Fig. 1.)

- While the locations of individual geothermal wells are not specified in this scenario, the criteria for their location are the same as for the power plants. However, geothermal resources, which are not below a zone permitting wells, can be obtained using slant drilling if the resources are within $1 / 4 \mathrm{mi}$ of a zone permitting wells. Therefore, the resources within a major fault zone could be utilized even though the wells or power plant could not be located in this zone. These criteria are applicable to al1 zones where geothermal operations are not permitted but resources exist.

\section{POWER PLANT SITES}

Figure 3 defines the regional boundaries where geothermal resources are assumed to exist. These resources can be obtained by direct or slant drilling. Figure 3 also defines the regions where a geothermal complex can actually be located.

Geothermal power plant sites were chosen from the allowed regions starting in the vicinity of current acticity in each KGRA. Subsequent power plant sites were located around the

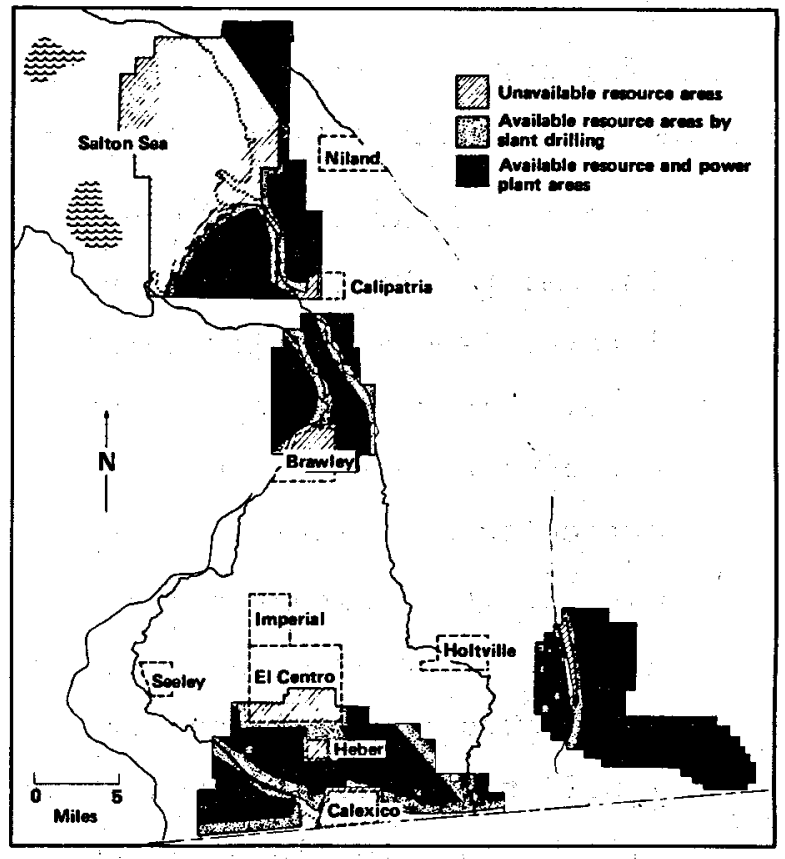

Fig. 3. Geothermal resource and power plant siting areas in Imperial Valley.

initial sites. Maximum distances between power plants were set so that the surrounding well field could support the power plant for the desired 30 years. The sites selected for the lower power levels were included in the higher levels. For example, the sites for the 1000-MW level include the four sites of the 400-MW level plus an additional six sites to achieve 1000 MW. An exception to this situation occurs in the siting patterns for 2020. Power plants built between 1980 and 1990 have been deleted from the siting patterns since the power plant life has been set at 30 years. 
Using this approach, siting patterns were developed for the 400-, 1000-, 2000-, 3000-, 4000-, and 8000MW levels of development. Figures 4-9 show the siting patterns for these levels prior to 2010. Within the KGRA boundaries, nearly a11 available land for power plant siting is consumed at the 8000-MW level (see Fig. 9). The siting patterns for the low, medium, and high projections in 2020 are shown in Figs. 10-12. Figure 12 shows the 8000-MW level siting pattern for 2020. The area of deleted power plant sites in each KGRA is clearly visible. Replacement sites have extended into the Westmorland area between the Salton Sea and Brawley KGRA's.
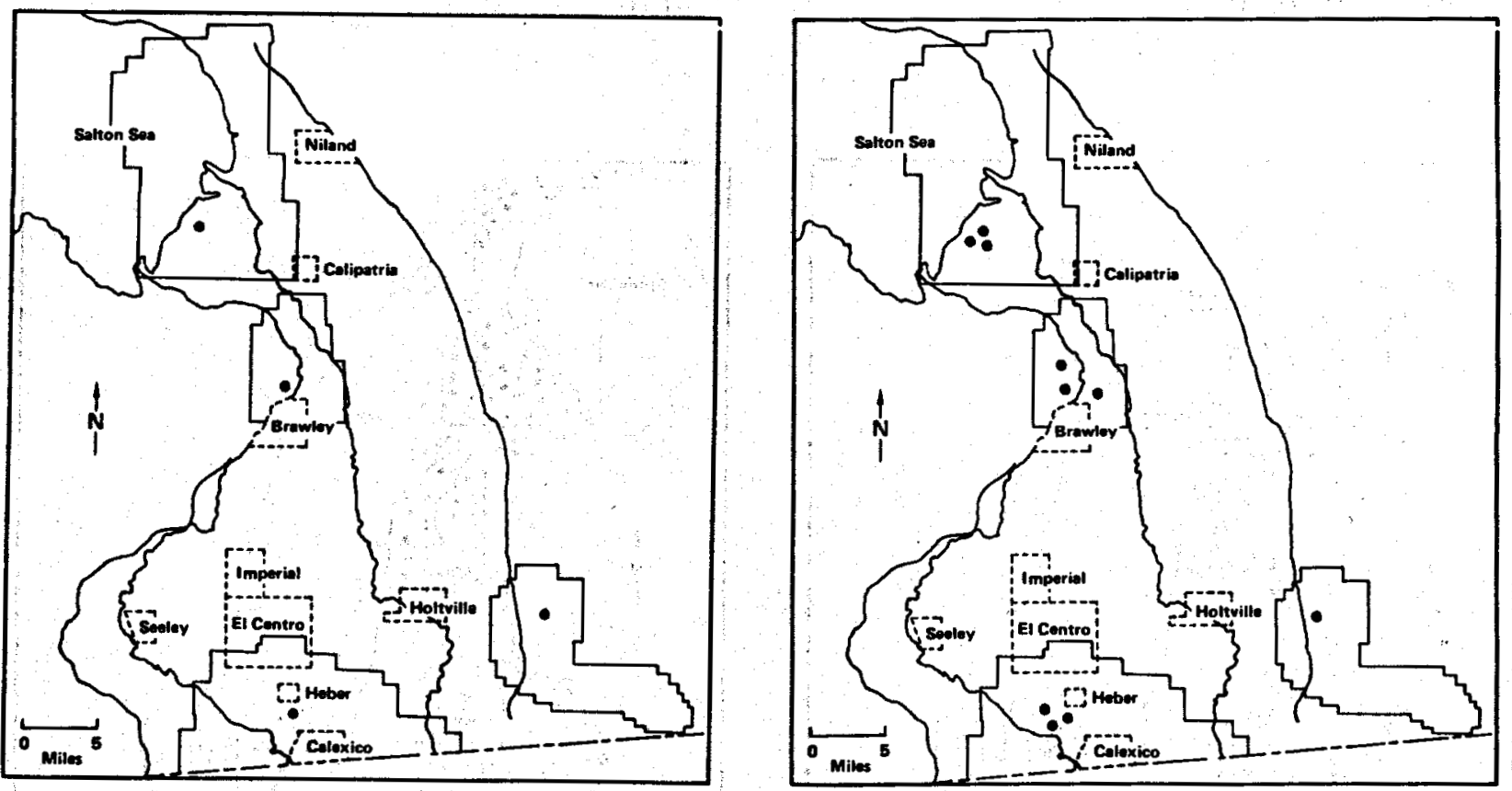

Fig. 4. Geothermal power plant siting pattern for the 400-MW power level prior to 2010.

Fig. 5. Geothermal power plant siting pattern for the 1000-MW power level prior to 2010 . 


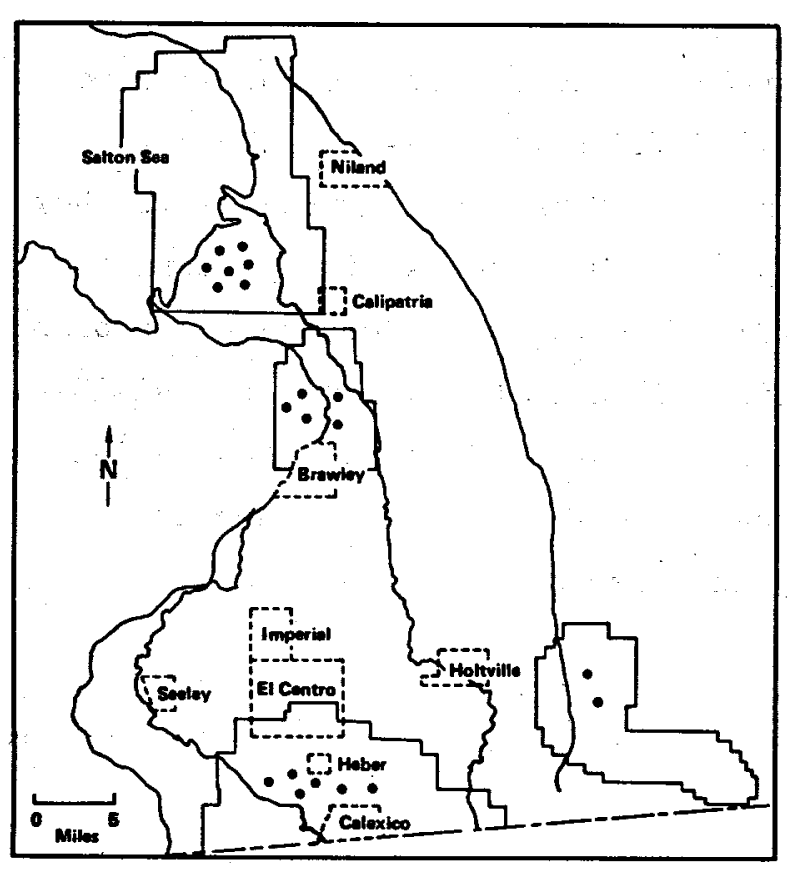

Fig. 6. Geothermal power plant siting pattern for the 2000-MW power level prior to 2010 .

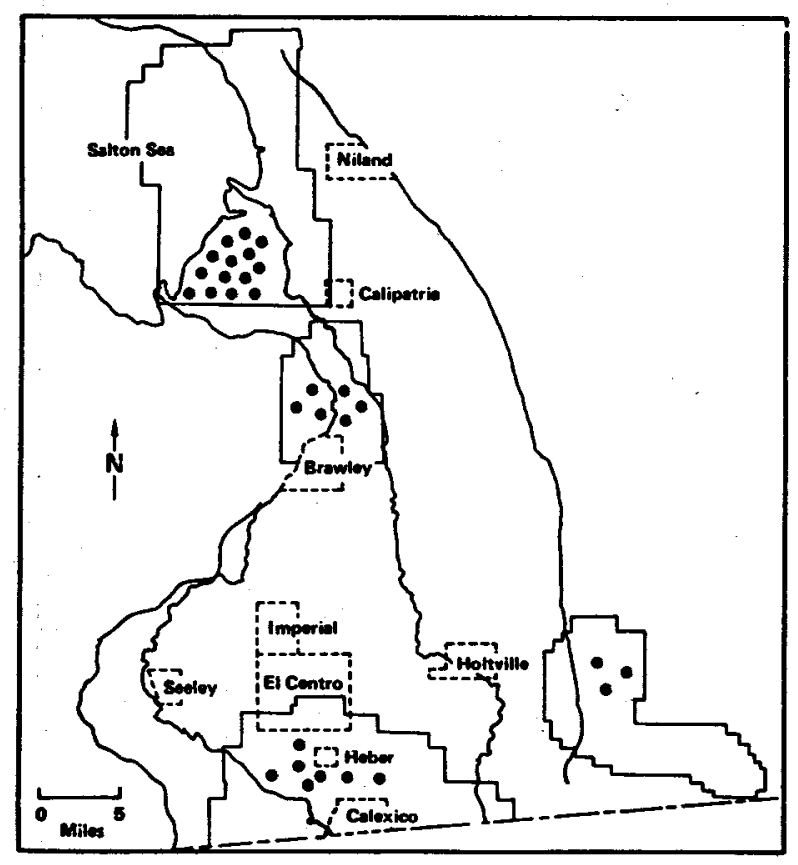

Fig. 7. Geothermal power plant siting pattern for the 3000-MW power level prior to 2010 .

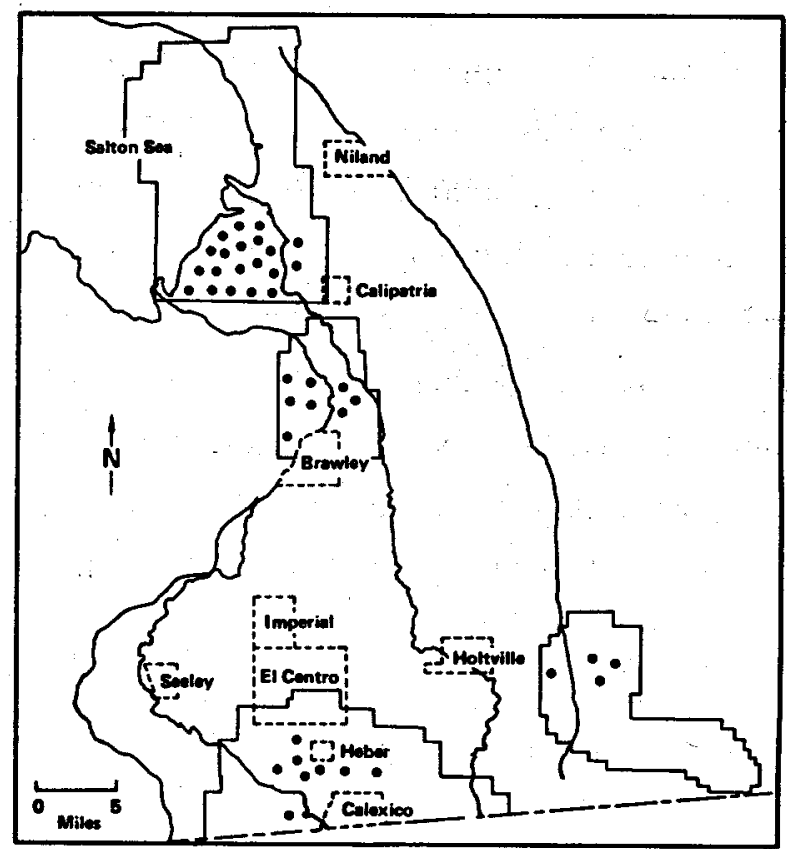

Fig. 8, Geothermal power plant siting pattern for the 4000-MW power level prior to 2010.

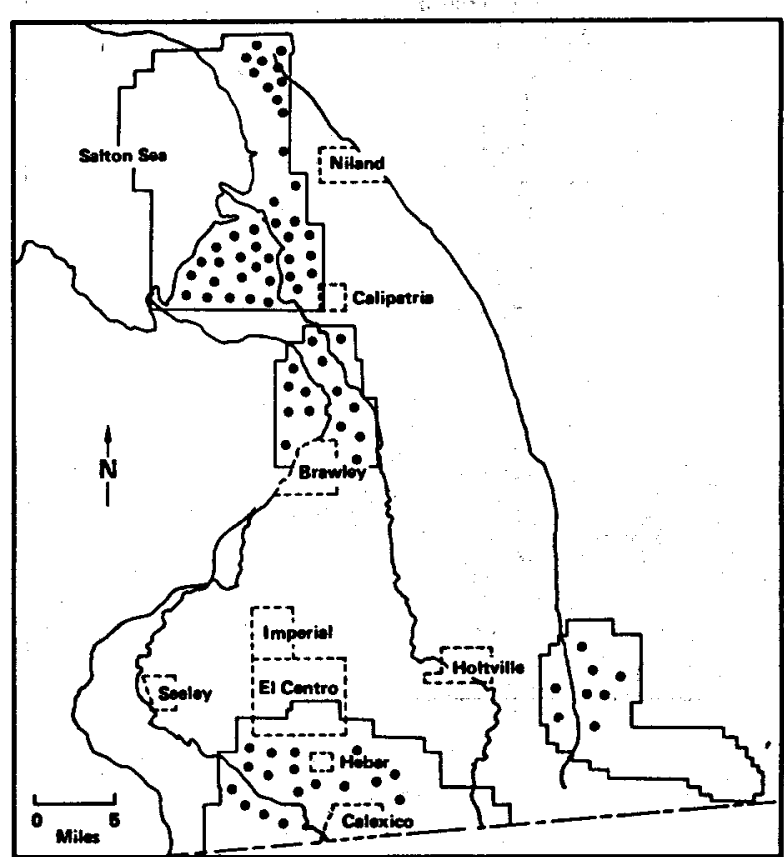

Fig. 9. Geothermal power plant siting pattern for the 8000-MW power level in 2010. 


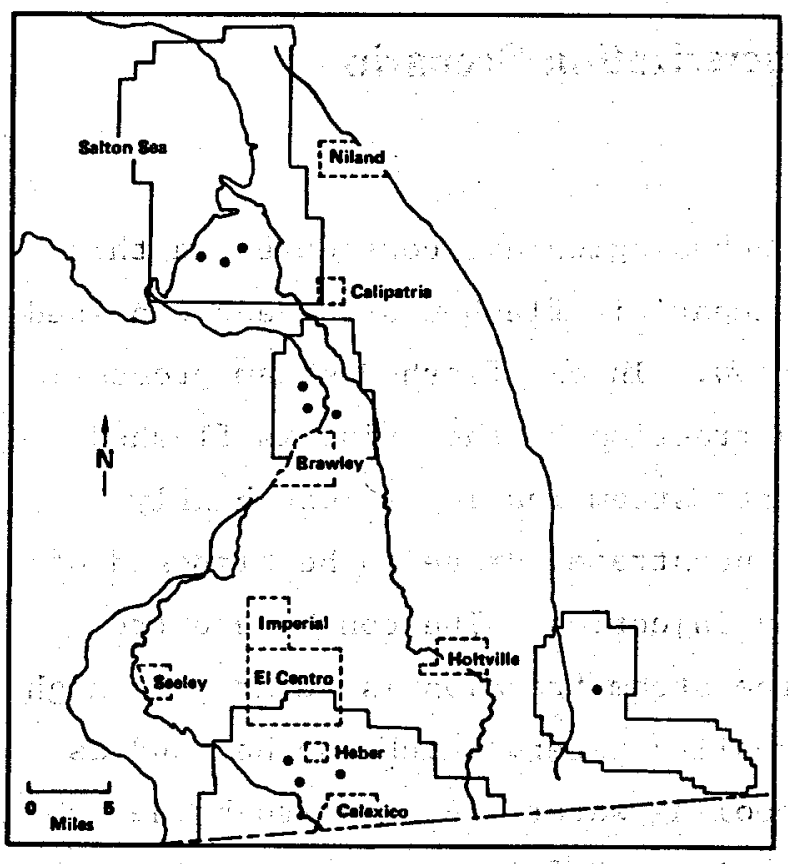

Fig. 10. Geothermal power plant siting pattern for the low growth projection of $1000 \mathrm{MW}$ in 2020.

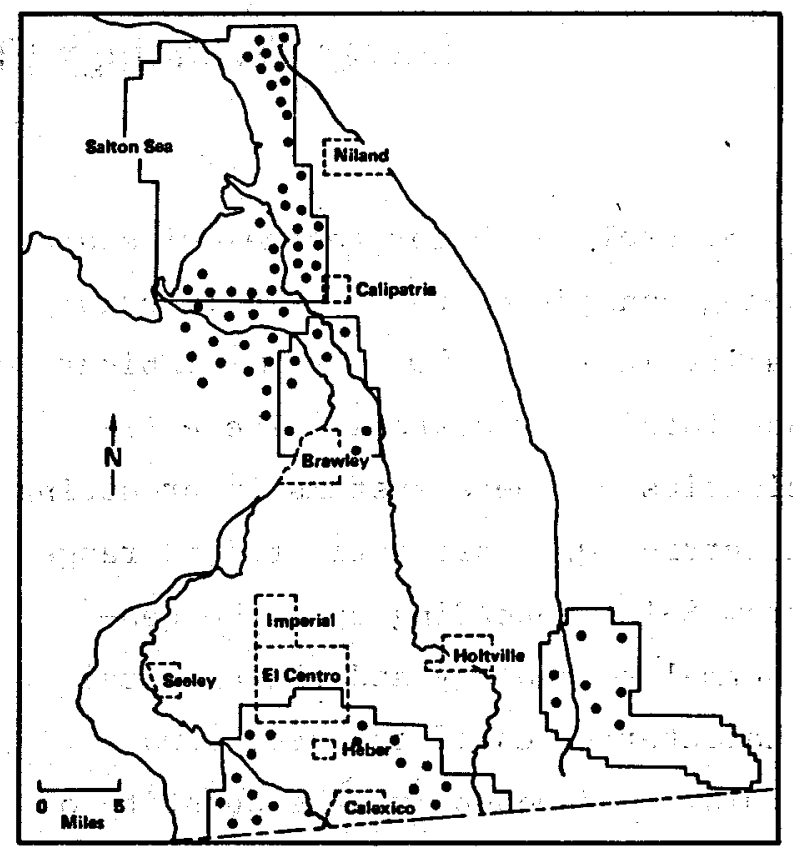

F1g. 12. Geothermal power plant sitIng pattern for the high growth projection of 8000 MW in 2020.

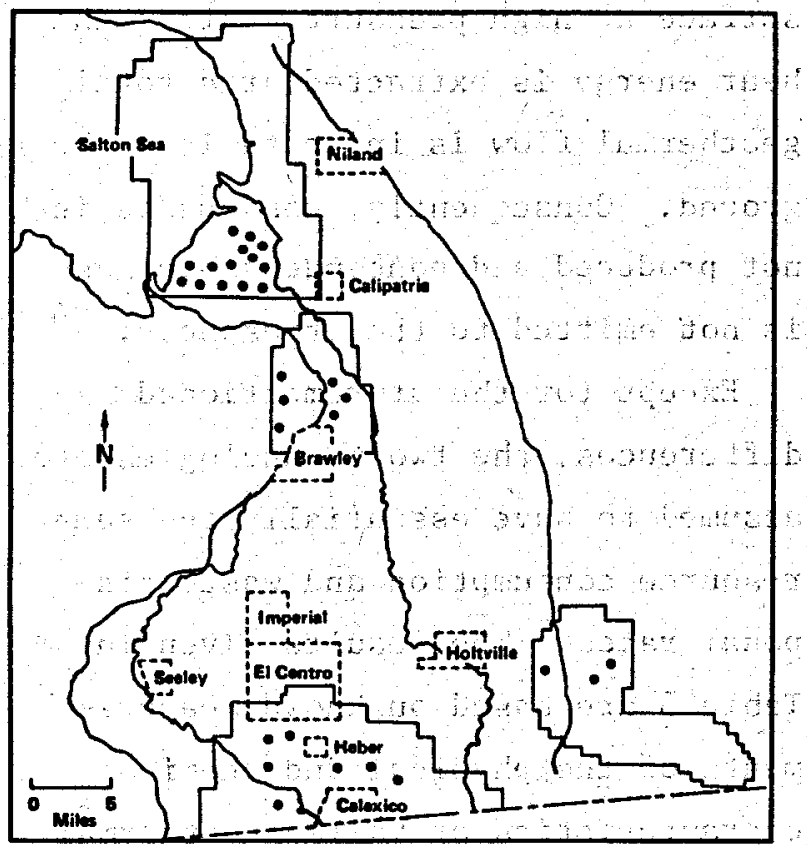

F1g. 11. Geothermal power plant sitIng pattern for the medium growth projection of 3000 MW in 2020 . 


\section{Energy Technology Characterization Scenario}

Several hot water technologies are being considered for use in Imperial Valley including flashed steam, binary, and total flow systems. The efficiencies of these systems in producing electric power are estimated to range from $8-18 \%$ depending upon the geothermal technology and the physical characteristics of the geothermal fluid. Consequently, the quantity of geothermal fluid consumed, cooling water consumed, and pollutants emitted to the environment depends on the geothermal technology and the nature of the geothermal resource.

The geothermal technologies, which are ultimately employed in the Valley, may vary considerably due to the variations in resource quality and the rate of technological advancement during the next 30 years. However, if the power plant is viewed from its environmental impacts, more concern can be placed on rates of resource consumption and waste disposal than on the intricacies of the technology by which these rates are achieved. Figure 13 illustrates this physical rate perspective.

Using this approach, an average power plant was characterized for each Valley KGRA with results shown in Table 3. Two basic conversion technologies are considered in this scenario: flashed steam and confined flow. In any flashed steam process, a fraction of the brine is flashed into steam leaving a more highly concentrated brine to be disposed of by injection. The condensate from the steam fraction is relatively high quality water, which can be used as cooling water. A steam-to-brine ratio of 0.3 is assumed in this work. The noncondensable gases contained in the geothermal fluid are emitted to the atmosphere. In a confined flow system a downhole pump is used to force the geothermal fluid to the surface at high pressure. After the heat energy is extracted, the total geothermal flow is injected into the ground. Consequently, condensate is not produced and noncondensable gas is not emitted to the atmosphere. Except for the aforementioned differences, the two technologies are assumed to have essentially the same resource consumption and waste disposal rates. The results given in Table 3 are based on known measurements of the physical and chemical characteristics of Valley geothermal resources and on general engineering principles relating to electric power plants. Power plant capacity, land 


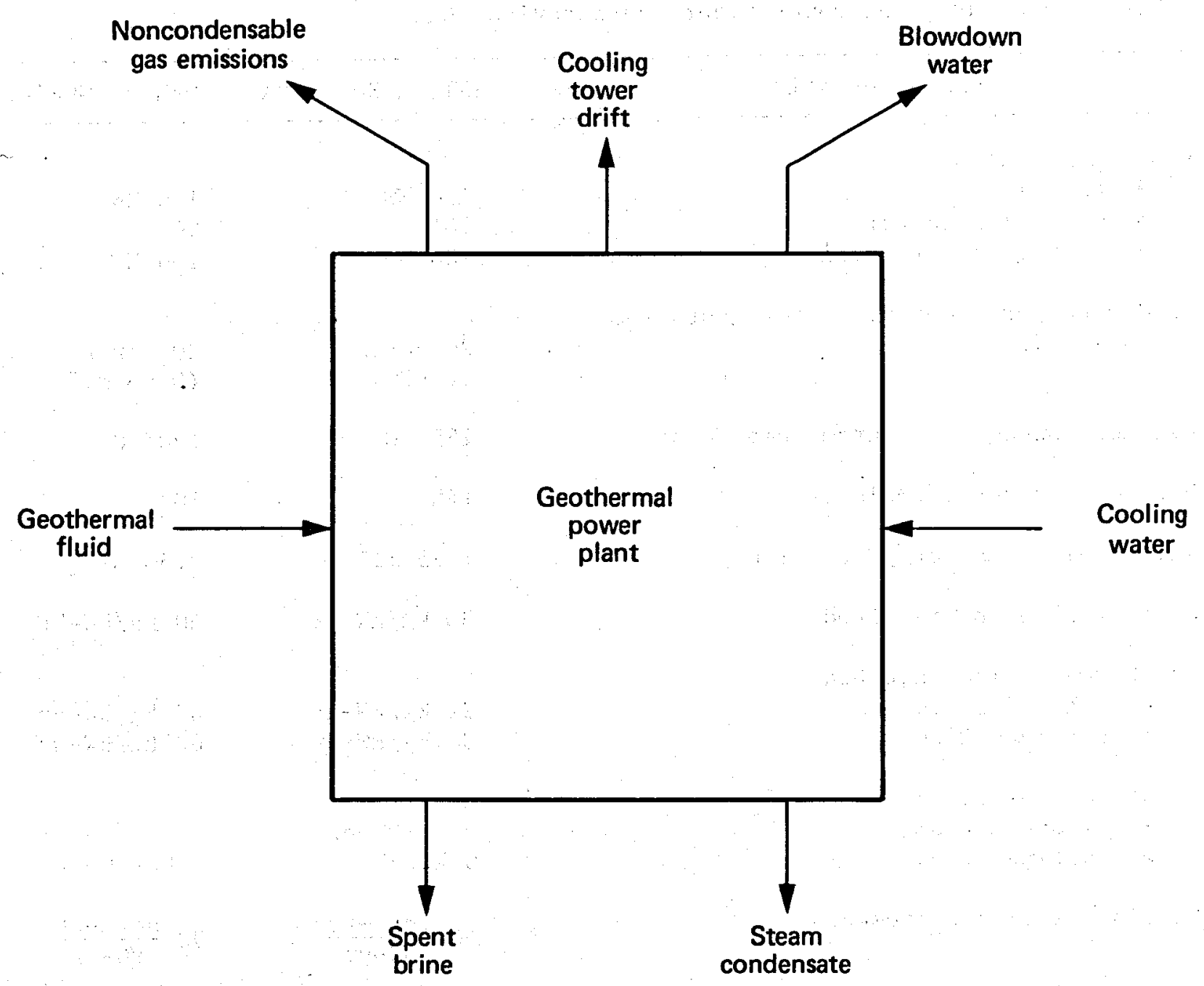

Fig. 13. Diagram of a geothermal power plant from a resource use and waste disposal viewpoint.

area, and well field size were discussed in the previous section. The remaining power plant characteristics are discussed in subseqeunt paragraphs.

Regardless of the technology used, geothermal power plants have low thermal efficiencies (8-18\%) in comparison to other power technologies such as fossil fuel (36\%). The reason is the relatively low temperature of geothermal resources. (The superheated steam used in a modern fossil fuel plant is approximately $540^{\circ}$ C.) Elliott ${ }^{20}$ gives the ratio of output power to condenser heat rejection for several different geothermal technologies over a range of resource 
Table 3. Resource and power plant characterization.

\begin{tabular}{|c|c|c|}
\hline Characteristic & Salton Sea KGRA & Other KGRA's \\
\hline \multicolumn{3}{|l|}{ Power plant size } \\
\hline - Capacity & $110 \mathrm{MW}$ & $110 \mathrm{MW}$ \\
\hline - Operation factor & $90 \%$ & $90 \%$ \\
\hline - Average power leve1 & $100 \mathrm{MW}$ & $100 \mathrm{MW}$ \\
\hline \multicolumn{3}{|l|}{ Land area per power plant for geothermal } \\
\hline facilities & $\begin{array}{l}20 \text { acres } \\
\left(0.03 \mathrm{mi}^{2}\right)\end{array}$ & $\begin{array}{l}20 \text { acres }_{2} \\
\left(0.03 \mathrm{mi}^{2}\right)\end{array}$ \\
\hline Average downhole resource temperature & $285^{\circ} \mathrm{C}$ & $190^{\circ} \mathrm{C}$ \\
\hline Net power plant efficiency & $14 \%$ & $10 \%$ \\
\hline Well field area per power plant & $1.25 \mathrm{mi}^{2}$ & $2.50 \mathrm{mi}^{2}$ \\
\hline Geothermal brine required & $30 \mathrm{~kg} / \mathrm{kW}-\mathrm{hr}$ & $60 \mathrm{~kg} / \mathrm{kW}-\mathrm{hr}$ \\
\hline \multicolumn{3}{|l|}{ Geothermal brine injected } \\
\hline $\begin{array}{l}\text { - Flashed steam } \\
\text { - Confined flow }\end{array}$ & $\begin{array}{l}21 \mathrm{~kg} / \mathrm{kW}-\mathrm{hr} \\
30 \mathrm{~kg} / \mathrm{kW}-\mathrm{hr}\end{array}$ & $\begin{array}{l}45 \mathrm{~kg} / \mathrm{kW}-\mathrm{hr} \\
60 \mathrm{~kg} / \mathrm{kW}-\mathrm{hr}\end{array}$ \\
\hline \multicolumn{3}{|l|}{ Steam condensate } \\
\hline $\begin{array}{l}\text { - Flashed steam } \\
\text { - Confined flow }\end{array}$ & $\begin{array}{l}9 \mathrm{~kg} / \mathrm{kW}-\mathrm{hr} \\
0 \mathrm{~kg} / \mathrm{kW}-\mathrm{hr}\end{array}$ & $\begin{array}{l}15 \mathrm{~kg} / \mathrm{kW}-\mathrm{hr} \\
0 \mathrm{~kg} / \mathrm{kW}-\mathrm{hr}\end{array}$ \\
\hline Cooling water requirements & $60 \frac{\mathrm{acre}-\mathrm{ft}}{\mathrm{MW}-\mathrm{yr}}$ & $90 \frac{\text { acre-ft }}{\mathrm{MW}-\mathrm{yr}}$ \\
\hline $\begin{array}{l}\text { - Cooling water evaporation losses } \\
\text { to the atmosphere }\end{array}$ & $50 \frac{\operatorname{acre}-f t}{\mathrm{MW}-\mathrm{yr}}$ & $75 \frac{\text { acre-ft }}{\text { MW-yr }}$ \\
\hline - Cooling water blowdown & $10 \frac{\text { acre-ft }}{\mathrm{MW}-\mathrm{yr}}$ & $15 \frac{\text { acre-ft }}{\mathrm{MW}-\mathrm{yr}}$ \\
\hline \multicolumn{3}{|l|}{$\begin{array}{l}\text { Hydrogen sulfide emissions to the } \\
\text { atmosphere }\end{array}$} \\
\hline $\begin{array}{l}\text { - Flashed steam } \\
\text { - Confined flow }\end{array}$ & $\begin{array}{l}1.2 \mathrm{~g} / \mathrm{kW}-\mathrm{hr} \\
0 \mathrm{~g} / \mathrm{kW}-\mathrm{hr}\end{array}$ & $\begin{array}{l}2.4 \mathrm{~g} / \mathrm{kW}-\mathrm{hr} \\
0 \mathrm{~g} / \mathrm{kW}-\mathrm{hr}\end{array}$ \\
\hline
\end{tabular}

temperatures. Using these results and assuming parasitic energy losses of about $10 \%$, the power plant efficiency can be calculated using the definition
For systems at a temperature of $190^{\circ} \mathrm{C}$, efficiencies ranged from $8-11 \%$, while systems using resources at a temperature of $285^{\circ} \mathrm{C}$ had efficiencies in the 13 to $17 \%$ range.

Efficiency $=\frac{\text { Output Power }}{\text { Output Power }+ \text { Condenser Heat Rejection }+ \text { Parasitic Losses }}$. 
The quantity of geothermal fluid needed to support a 100-MW power plant depends significantly on the resource temperature as well as the geothermal technology. As previous1y mentioned, Pines and Green ${ }^{14}$ have designed a 10-MW power plant utilizing high saline brines at temperatures of $200^{\circ} \mathrm{C}$ and $300^{\circ} \mathrm{C}$. Scaling these plants to $100 \mathrm{MW}$, the geothermal brine requirements are $60 \mathrm{~kg} / \mathrm{kW}-\mathrm{hr}$ and $30 \mathrm{~kg} / \mathrm{kW}-\mathrm{hr}$, respectively.

Large quantities of water are needed for use in evaporative cooling towers in order to reject waste heat from the power plant. The total water requirement is the sum of evaporative losses in the cooling tower plus blowdown water. The evaporative losses for the operating power plant efficiencies given in Table 3 were calculated by assuming a $20^{\circ} \mathrm{F}$ temperature change across the condenser and an evaporation loss rate equal to $0.75 \%$ of the condenser flow rate of $10^{\circ} \mathrm{F}$ change in the cooling water temperature. 21 The blowdown rate was assumed to be $20 \%$ of the evaporation loss rate.

The atmospheric pollutant of major concern from a geothermal power plant in the Valley is hydrogen sulfide $\left(\mathrm{H}_{2} \mathrm{~S}\right)$. Initial $\mathrm{H}_{2} \mathrm{~S}$ source measurements have been made by Lawrence Livermore Laboratory at the Niland
Test Facility in the Salton Sea KGRA. The $\mathrm{H}_{2} \mathrm{~S}$ fraction of the noncondensable gas was found to be about $0.25 \%$ (volume) with the noncondensable gases making up $2 \%$ (weight) of the total geothermal fluid. ${ }^{22}$ Assuming a constant $\mathrm{H}_{2} \mathrm{~S}$ content in the geothermal fluid throughout the Valley, the 100-MW power plants projected in this scenario would have an $\mathrm{H}_{2} \mathrm{~S}$ source strength of $35 \mathrm{~g} / \mathrm{s}$ in the Salton Sea KGRA and $70 \mathrm{~g} / \mathrm{s}$ in the Brawley, Heber, and East Mesa KGRA's. These emission rates are much lower than the rate at the Cerro Prieto power plant located in the southern end of the Salton Trough. Scaling this power plant to $100 \mathrm{MW}$, it would have an $\mathrm{H}_{2} \mathrm{~S}$ emission rate of $900 \mathrm{~g} / \mathrm{s.*}$ This is an indication that future source measurements in the Valley may find the $\mathrm{H}_{2} \mathrm{~S}$ content to be considerably higher.

*This emission rate was obtained from Axtmann. 23 Measurements by Mercado24 indicate an emission rate of $300 \mathrm{~g} / \mathrm{s}$ per $100 \mathrm{MW}$ from the stacks alone. At The Geysers, roughly $1 / 3$ of the $\mathrm{H}_{2} \mathrm{~S}$ emission is from the stacks and 273 is from the cooling towers. Using this ratio, the $\mathrm{H}_{2} \mathrm{~S}$ emission rates presented by the two authors are in excellent agreement. 


\section{Geothermal Electric Power Development Analysis}

The geothermal electric power development levels projected in this scenario are sufficiently large to have considerable effect on Imperial Valley's environment, economy, and quality of life. Some of these effects are discussed herein with estimates of possible impacts. More detailed assessments of this scenario are left for future work.

POWER PLANT CONSTRUCTION AND WELL DRILLING RATES

The power plant construction rate is proportional to the electric power growth rate if the power plants are installed in units of constant size. An additional 100-MW unit must be built every year to meet the medium growth projection. For the low and high growth cases, the average time between new units is respectively 2.5 years and 6 months. Another view of the activity needed to achieve these projections can be gained by considering the number of geothermal wells that must be drilled each year.

The average flow rate of the geothermal wells drilled in the Salton Sea KGRA is about $200,000 \mathrm{~kg} / \mathrm{hr} .^{5}$ Using this value, approximately 15 production wells are needed to support a 100-MW power plant. Assuming that total injection can be achieved with half as many wells, eight are needed for injection. In addition, replacement wells are needed to supplement the flow of the production wells since yields decrease with time. A replacement rate of two production wells every 5 years is adopted for this analysis. Therefore, 35 wells must be drilled to support a single 100-MW power plant in the Salton Sea KGRA for 30 years.

Power plants located in the Brawley, Heber, and East Mesa KGRA's require twice as much geothermal fluid to produce the same electrical output due to the lower temperature of the fluids in these KGRA's. Consequently, power plants in these KGRA's will require about twice as many wells to be drilled.

Using these estimates, the well drilling requirements for each of the three growth projections are calculated and the results are in Table 4. Between the first year of development and 2010,16 to 22 new wells are needed each year to meet the low growth projection; 42 to 53 new wells are needed each year to meet the medium growth projection; and 105 to 130 new wells are needed each year to meet the high growth projection. (The number of new wells grows with 
Table 4. Geothermal well requirements in Imperial Valley.

\begin{tabular}{|c|c|c|c|}
\hline Year & $\begin{array}{l}\text { Power } \\
\text { leve1, MW } \quad \text { drilled per yra }\end{array}$ & $\begin{array}{l}\text { Rigs } \\
\text { employed } \mathrm{b}\end{array}$ & $\begin{array}{l}\text { Wells } \\
\text { drilled to date }\end{array}$ \\
\hline \multicolumn{4}{|c|}{ Low growth projection $-\approx 40 \mathrm{MW}$ per yr } \\
\hline 1985 & $<100$ & 3 & 20 \\
\hline 1995 & 400 & 3 & 180 \\
\hline 2010 & 1000 & 4 & 480 \\
\hline \multicolumn{4}{|c|}{ Medium growth projection $-\approx 100 \mathrm{MW}$ per yr } \\
\hline 1985 & 400 & $\therefore$ & 160 \\
\hline 1995 & 1400 & 8 & 605 \\
\hline 2010 & $\because 53$ & 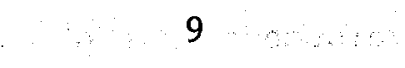 & 1355 \\
\hline Iigh & projection $-\approx 250 \mathrm{MW}$ per yr & 86 & 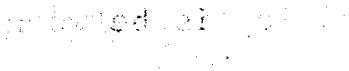 \\
\hline 1985 & 1250 & 18 & 500 \\
\hline 1995 & 4000 & 19 & 1600 \\
\hline 2010 & 8000 & 22 & 3450 \\
\hline
\end{tabular}

ancludes both production and injection wells.

${ }^{b}$ Assumes one rig can drill six wells per yr.

time due to the increased need for replacement wells.) If a single rig drills six wells per year, the approximate number of rigs needed to work continuously in the Valley are: four in the low projection; eight in the medium projection; and 20 in the? high projection.

A comparison can be made between these levels of activity and the current situation at The Geysers geothermal field in northern California. As previously mentioned, The Geysers electrical capacity is growing at a rate of $100 \mathrm{MW}$ per year. If an equal rate of growth is achieved in the
Valley, then the situation described by the medium growth projection is the most accurate of the three projections.

The situation is quite different when the rates of resource exploration and well drilling are considered. Power plants at The Geysers require fewer support wells due to the higher geothermal steam temperature. In addition, fewer injection wells are needed since a larger fraction of the geothermal steam is condensed and used in the cooling towers. The total number of wells used to produce 100 MW of power at The Geysers is less 
than half the number projected in this scenario for Imperial Valley. Therefore, if the well drilling rate in the Valley is equal to the present rate at The Geysers, then electrical capacity in the Valley will grow at the rate of 30 to $50 \mathrm{MW}$ per year.

These comparisons imply a growth rate for the Valley between the low and medium growth projections. As shown in Fig. 2, the national goal for geothermal development in the Valley is between the medium and high growth projections. At the peak growth rate in the 1985 to 1995 time period, the national goal is growing at a rate of $350 \mathrm{MW}$ per year. Consequently, if this goal is to be achieved, geothermal development in. the Valley must be significantly accelerated.

LAND USE

In the power plant siting section of this report, it was assumed that only a small fraction of the agricultural land in the Valley would be taken out of production in order to construct geothermal facilities (e.g., wells, pipelines, cooling towers, etc.). Using the 20-acre per 100-MW power plant concept adopted in this scenario, the fraction of agricultural land lost to geothermal power plant operations is shown in Table 5 and is quite small. At the highest level considered ( 8000 MW) less than $0.5 \%$ of the existing agricultural land area is used. Even if the land requirement per power plant were several times as large as the 20-acre figure, the fraction of the agricultural land taken from production would be sma11.

While the amount of land directly removed from agriculture to support geothermal facilities may be relatively small, the land lost

Table 5. Area (In acres) occupied by geothermal facilities. ${ }^{a}$

\begin{tabular}{ccccccc}
\hline $\begin{array}{c}\text { Power } \\
\text { leve1, MW }\end{array}$ & $\begin{array}{c}\text { Salton Sea } \\
\text { KGRA }\end{array}$ & $\begin{array}{c}\text { Brawley } \\
\text { KGRA }\end{array}$ & $\begin{array}{c}\text { Heber } \\
\text { KGRA }\end{array}$ & $\begin{array}{c}\text { East Mesa } \\
\text { KGRA }\end{array}$ & $\begin{array}{c}\text { Total } \\
\text { agricultural 1and }\end{array}$ \\
\hline 400 & 20 & 20 & 20 & 20 & 80 & $0.01 \%$ \\
1000 & 60 & 60 & 60 & 20 & 200 & $0.04 \%$ \\
3000 & 280 & 120 & 140 & 60 & 600 & $0.12 \%$ \\
8000 & 800 & 280 & 360 & 160 & 1600 & $0.30 \%$ \\
\hline
\end{tabular}

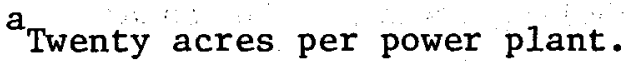

${ }^{b}$ Approximately 450,000 acres of agricultural land are in Imperial Valley. Most of the East Mesa land is not agricultural.
} 
Indirectly to geothermal activities could be significant if not properly planned for. At higher levels of development, power plants w111 be spread over large areas of agricul-. tural land. Pipelines from wells to power plants, power lines transmitting electricity from plants, and canals transporting cooling water to plants could disrupt agricultural practices. Planning of these routes prior to large scale development will be needed to minimize interference with $i$ agriculture.

COOLING WATER REQUIREMENTS

Quantities of cooling water required by the scenario are listed in Table 6 for each KGRA and for power levels ranging from 400 to 8000 MW. In order to meet these water demands, a number of potentially available sources of water exists in the Valley: the Colorado River, agricultural and municipal waste water from Mexico, Imperial Valley agricultural drainage water, the Salton Sea, ground water, and steam condensate produced in the geothermal power plants.

The most attractive of these sources is the steam condensate, as the use of this source does not reduce the current supply to other water users in the Valley. Table 3 indicates that a flashed steam-type power plant produces 62.4 acre-ft/MW-yr of water from the steam condensate when located in the Salton Sea KGRA and 103.9 acre-ft/MW-yr when located in one of the other three KGRA's. The cooling water requirements in these KGRA's are 60 and 90 acre-ft/MW-yr, respectively. The steam condensate is therefore sufficient to meet the cooling water demands and no additional water is required.

The situation is quite different, however, If total injection is required. Either the steam condensate is injected or an equivalent amount of water from another source

Table 6. Cooling water requirements (acre-ft/yr).

\begin{tabular}{cccccc}
\hline $\begin{array}{c}\text { Power } \\
\text { leve1, MW }\end{array}$ & $\begin{array}{c}\text { Salton Sea } \\
\text { KGRA }\end{array}$ & $\begin{array}{c}\text { Brawley } \\
\text { KGRA }\end{array}$ & $\begin{array}{c}\text { Heber } \\
\text { KGRA }\end{array}$ & $\begin{array}{c}\text { East Mesa } \\
\text { KGRA }\end{array}$ & Tota1 \\
\hline 400 & 6,000 & 9,000 & 9,000 & 9,000 & 33,000 \\
1,000 & 18,000 & 27,000 & 27,000 & 9,000 & 81,000 \\
3,000 & 84,000 & 54,000 & 63,000 & 27,000 & 228,000 \\
8,000 & 240,000 & 126,000 & 162,000 & 72,000 & 600,000 \\
\hline
\end{tabular}


is injected. In either case, a quantity of water equal to the cooling water demand is required from a source external to the power plant. This is also the case for a confined flow type geothermal power plant where no steam condensate is produced.

The main source of water in the Valley is the Colorado River...An. average of about 2.8 million acre-ft per year is imported via the Al1American Cana1. The water is distributed by the Imperial Irrigation District through the Valley where it is used primarily for agricultural purposes. Agricultural drainage is collected in the New and Alamo Rivers. These flows are augmented by approximately 120,000 acre-ft/yr of waste water from Mexico, bringing the total average flow of the two Rivers to 420,000 and 650,000 acre-ft/yr, respectively. The waste water is dumped into the Salton Sea, which has a TDS content of $39,000 \mathrm{ppm}$. In the East Mesa area, groundwater recharged by the unlined A11-American and Coachella Canals is another potential water supply.

The highest quality source of water is that directly from the Colorado River (TDS $\approx 900 \mathrm{ppm}$ ). However, use of this water is considered to be unlikely because it is needed to irrigate crops and to control salinity in the Valley.
The most promising source of cooling water apepars to be the agricultural waste water flowing into the New and Alamo Rivers. This supply is of sufficient quality to support over $8000 \mathrm{MW}$ of geothermal electric power. The TDS content of this water is about $2300 \mathrm{ppm}$ in the Alamo River and between 3300 and 4300 ppri in the New River; however, chemical treatment may still be required before it can be used for cooling water. Since the flow in these rivers is not uniform, distribution and storage problems will probably arise at the higher levels of development. Also, the loss of water to the Salton Sea will be very large.

In comparison to other electric power technologies, geothermal electric power consumes a large quantity of cooling water, due to the relatively low temperature of the geothermal fluids resulting in a low operating efficiency. The geothermal power plants described in this scenario consume 60 to 90 acre-ft/MW-yr depending on their location in the Valley. A large scale fossil fuel power plant requires about 14 acre-ft/ MW-yr of cooling water. Therefore, the geothermal power plants consume from four to six times as much cooling water as the equivalent electrical capacity fossil fuel power plant. 
HYDROGEN SULFIDE EMISSIONS

Pollutants are not emitted to the atmosphere if the geothermal power plants are of the confined flow type. However, if all or a significant number of power plants are of the flashed steam type, large quantities of $\mathrm{H}_{2} \mathrm{~S}$ are released to the atmosphere. Using the emission rates listed in Table 3, each 100-MW unit in the Salton Sea KGRA emits $120 \mathrm{~kg} / \mathrm{hr}$. In the other KGRA's, each 100-MW unit releases $240 \mathrm{~kg} / \mathrm{hr}$. Assuming all the power plants are of the flashed steam type, approximately $350,000 \mathrm{~kg}$ of $\mathrm{H}_{2} \mathrm{~S}$ are released to the atmosphere each day at the 8000-MW power level.

Hydrogen sulfide is emitted from the noncondensable gas stack and from cooling towers into the atmosphere where it is dispersed by the wind. A crude estimate of the average $\mathrm{H}_{2} \mathrm{~S}$ concentration is obtained by using a simple box model. In this model, the pollutant concentration is constant within a region (box) surrounding the source. The pollutant travels through the box at a speed equal to the average wind speed. Using these assumptions, the pollutant concentration in the box is

$$
\mathrm{C}=\frac{\mathrm{Q}}{\mathrm{W} \cdot \mathrm{H} \cdot \mathrm{U}},
$$

where $\mathrm{C}$ is the pollutant concentration, $Q$ is the source strength, $W$ and $H$ are the width and height of the box, and $\mathrm{U}$ is the average wind speed. Approximating the air space above the Valley by a box which is $65-\mathrm{km}$ wide and $150-\mathrm{m}$ high and letting $\mathrm{U}=3.8 \mathrm{~m} / \mathrm{s}$, the average wind speed in the Valley, the average $\mathrm{H}_{2} \mathrm{~S}$ concentration in the box is calculated for each source strength. The results are shown in Fig. 14.

The California air quality standard for $\mathrm{H}_{2} \mathrm{~S}$ requires the $1-\mathrm{hr}$ average concentration at any ground level location to be less than $0.03 \mathrm{ppm}$ by volume $\left(42 \mu \mathrm{g} / \mathrm{m}^{3}\right)$. The box model calculations indicate that this pollutant concentration is exceeded

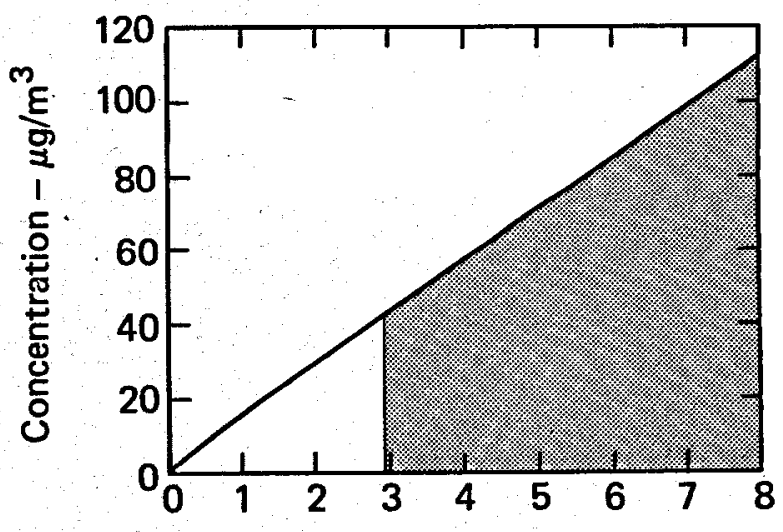

Electric power level - $1000 \mathrm{MW}$

Fig. 14. Box model calculation of the Valley-wide average hydrogen sulfide $\left(\mathrm{H}_{2} \mathrm{~S}\right)$ concentration as a function of geothermal power level. The California standard for the maximum average concentration over a $1-\mathrm{h}$ period is $0.03 \mathrm{ppm}$ by volume $\left(42 \mu \mathrm{g} / \mathrm{m}^{3}\right)$. 
at the 3000-MW power level and above. However, box model calculations tend to give a low estimate of the maximum $1-\mathrm{hr}$ average concentration. There are two main reasons: first, the wind speed is often much less than the average wind speed resulting in higher pollutant concentrations; second, the pollutant concentration is not uniform throughout the Valley, but in general is higher in the KGRA's where the pollutants are produced.
Therefore, the California standard can be expected to be exceeded at even lower power levels than 3000 MW.

These simple calculations indicate that some degree of $\mathrm{H}_{2} \mathrm{~S}$ control is necessary to meet the California air quality standard. More detailed calculations are needed to determine the level to which emissions must be reduced so that the standard is not exceeded throughout the Valley. 


\section{Acknowledgments}

The author is indebted to the entire Imperial Valley Environmental Project staff for many helpful discussions and a critical review of the draft manuscript. I would like to especially thank D. W. Layton for his suggestions concerning cooling water requirements and $K$. Haven and C. H. Ha11 for their assistance in developing the institutional constraints to power plant siting used in this scenario. 


\section{References}

1. D. Towse, An Estimate of the Geothermal Energy Resource in the Salton Trough, California, Lawrence Livermore Laboratory, Rept. UCRL-51851 (1975).

2. J. L. Renner, D. E. White, and D. L. Williams, "Hydrothermal Convection Systems," in Assessment of Geothermal Resources of the United States, U.S. Geological Survey, Circ. 726 (1975).

3. S. Biehler and T. Lee, Final Report on a Resource Assessment of the Imperial Valiey, University of California, Riverside, DLRI Rept. No. 10, Under NSF/ERDA Grant AER 75-08793 (1977).

4. M. Nathenson and L. J. P. Muffler, "Geothermal Resources in Hydrothermal Convection Systems and Conduction - Dominated Areas," in Assessment of Geothermal Resources of the United States, U.S. Geological Survey, Circ. 726 (1975).

5. D. L. Ermak and M. Buchanan, "Geothermal Resources," in A Description of Imperial Valley, California for Use in Assessing the Impacts of Geothermal Energy Development, Lawrence Livermore Laboratory, Rept. UCRL-52121 (1975).

6. A. L. Austin, G. H. Higgins, J. H. Howard, The Total Flow Concept for Recovery of Energy from Geothermal Hot Brine Deposits, Lawrence Livermore Laboratory, Rept. UCRL-51366 (1973).

7. E. Behrin and R. L. Cooper, California Energy Outlook, Lawrence Livermore Laboratory, Rept. UCRL-51966 (1975).

8. California Energy Resources Conservation and Development Commission, Chap. IV: "Analysis of Utility Supply Plans and Important Supply Planning Issues," in EZectricity Forecasting and Planning Report (1976).

9. California Energy Resources Conseṛvation and Development Commission, Chap. VII: "Alternative Supply Scenarios," in Electricity Forecasting and Planning Report (1976).

10. C. D. Fredrickson, Analysis of Requirements for Accelerating the Development of Geothermal Energy Resources in California, Jet Propulsion Laboratory, California Institute of Technology, under ERDA/NASA Interagency Agreement EY76-A-03-0959, Rept. to be published.

11. F. J. Dan, D. E. Hersam, S. K. Kho, and L. R. Krumland, "Development of a Typical Generating Unit at The Geysers Geothermal Project - A Case Study," in Proc. 2nd. U.N. Symp. DeveZopment and Use of Geothermal Resources, U.S. Government Printing office, Washington, D.C. (1975). 
12. S. Peters, "Civil Engineering Features of Geothermal Power Plant," J. of the Power Division, Proc. Am. Soc. Civil Engineers 100, No. P02 (1974).

13. E. E. Hughes, "Geothermal Energy," in Control of Environmental Impacts from Advanced Energy Sources, Environmental Protection Agency, Rept. EPA 600/2-74-002 (1974).

14. H. S. Pines and M. A. Green, The Use of Program GEOTHM to Design and Optimize Geothermal Power Plant Cycles, Lawrence Berkeley Laboratory, Rept. LBL-4454 (1976).

15. T. H. Cahraman, "The Interrelationship Between Federa1, State, and Local Regulatory Agencies on the Development of the Geotherma1 Resource in California," in Proc. National Conf. on Geothermal Energy, Vol. II, under NSF Grant No. G1-36250 (1973).

16. U.S. Department of the Interior, Final Environmental Statement for the Geothermal Leasing Program, Vol. II (1973), p. 300.

17. Imperial County Planning Department, Current Land Use Plan - Northern and . Southern Planning Area, Imperial Valley (1973).

18. Imperial County Planning Department, Imperial County UZtimate Land Use PZan (1973).

19. Imperial County Department of Public Works, Terms, Conditions, Standards, and Application Procedures for Initial Geothermal Development Imperial County (1971).

20. D. G. Elliott, Comparison of Brine Production Methods and Conversion Processes for Geothermal Electric Power Generation, Environmental Quality Laboratory, Rept. EQL No. 10 (1975).

21. U - Environmenta1 Protection Agency, Reviewing Environmental Impact ements - Power PZant Cooling Systems, Engineering Aspects, Natural

Environmenta1 Research Center, Rept. EPA-660/2-73-016 (1973).

22. P. Gudiksen, Imperial Valley Environmental Project: Progress Report on Air Quality, Lawrence Livermore Laboratory, Rept. UCRL-50044-76-1 (1976).

23. R, C. Axtmann, "Emission Control of Gas Effluents from Geothermal Power Plants," Environ. Lett. 8 (1975), p. 135.

24. S. G. Mercado, "Cerro Prieto Geothermal Project: Pollution and Basic Protection," in Proc. 2nd U.N. Symp. Development and Use of Geothermal Resources, U.S. Government Printing office (1975).

$\mathrm{JAD} / \mathrm{gw} / \mathrm{vt}$

מُU.S.: GPO: 789-086/4911 